\title{
Crystal structures of the carboxyl cGMP binding domain of plasmodium falciparum cGMP- dependent protein kinase reveals a novel salt bridge crucial for activation
}

\author{
Jeong Joo Kim ${ }^{1 *}$, Eduardo Sanabria Figueroa ${ }^{1,4}$, Eugen Franz ${ }^{2}$, Daniela Bertinetti ${ }^{2}$, Friedrich Herberg ${ }^{2}$, Choel Kim ${ }^{1,3}$ \\ From 6th International Conference on cGMP: Generators, Effectors and Therapeutic Implications \\ Erfurt, Germany. 28-30 June 2013
}

\section{Background}

Plasmodium falciparum cGMP-dependent protein kinase (pfPKG) is a validated therapeutic target of malaria. As a key regulator of its life cycle, pfPKG plays a crucial role in both the sexual and asexual blood-stages that cause malaria pathology. Inhibiting pfPKG blocks proliferation and transmission of the parasite [1,2]. However the development of pfPKG-specific inhibitor has been greatly hampered by the lack of high-resolution structure information to guide drug design.

Targeting the ATP binding site of pfPKG is an approach commonly associated with low specificity and toxicity [3]. Therefore, we aim to target a domain that is unique to this kinase, the cyclic nucleotide binding (CNB) domain. Since previous studies demonstrated the fourth-cyclic nucleotide binding (CNB-D) domain of pfPKG to be the most important for the kinase activation [4] we focused on this domain to understand its role in cGMP dependent activation.

\section{Results}

To understand the functional roles of the CNB-D domain in pfPKG activation, we determined crystal structures of CNB-D with and without cGMP at 1.9 and $2.0 \AA$, respectively. The structure of the cGMP complex reveals that CNB-D binds cGMP through [1] leucine and arginine residues on the $\beta 5$ strand and a threonine within the phosphate binding cassette ( $\mathrm{PBC}$ ) that interact specifically with the guanine moiety through hydrogen bonding
[2] a conserved arginine residue within the $\mathrm{PBC}$ that provides a hydrophobic capping interaction with cGMP. The structure also shows that the side chain of the conserved arginine residue within the $\mathrm{PBC}$ interacts with two conserved glutamine and aspartic acid residues on the $\alpha \mathrm{C}$-helix forming a stable salt bridge. Mutation of the salt bridge forming residues drastically reduces its affinity for cGMP and increases activation constants $(\mathrm{Ka})$ of the full-length kinase. Furthermore, comparison with the apo structure shows that the salt bridge stabilizes the cGMP bound conformation and shields the cGMP binding pocket from solvent by anchoring the highly dynamic $\alpha C$-helix.

\section{Conclusion}

Our structures and accompanying mutagenesis studies demonstrate functional roles of the CNB-D domain in cGMP binding and activation. Our crystal structures also reveal the molecular details of cGMP pocket and the unique salt bridge that can be differentially targeted for the development of pfPKG-specific inhibitor.

\footnotetext{
Authors' details

'Department of Pharmacology, Baylor College of Medicine, One Baylor Plaza, Houston, Texas, USA. ${ }^{2}$ Department of Biochemistry, University of Kassel,

Kassel, Germany. ${ }^{3}$ Verna and Marrs McLean Department of Biochemistry and Molecular Biology, Baylor College of Medicine, Houston, Texas, USA. ${ }^{4}$ Current address, Department of Pharmacology, School of Medicine, Emory University. Atlanta, GA, USA.
}

\footnotetext{
* Correspondence: jeongjok@bcm.edu

'Department of Pharmacology, Baylor College of Medicine, One Baylor Plaza, Houston, Texas, USA

Full list of author information is available at the end of the article
}

(c) 2013 Kim et al; licensee BioMed Central Ltd. This is an Open Access article distributed under the terms of the Creative Commons 


\section{References}

1. McRobert L, Taylor CJ, Deng W, Fivelman QL, Cummings RM, Polley SD, Billker O, Baker DA: Gametogenesis in Malaria Parasites Is Mediated by the cGMP- Dependent Protein Kinase. PLoS Biol 2008, 6:e139.

2. Taylor HM, McRobert L, Grainger M, Sicard A, Dluzewski AR, Hopp CS, Holder AA, Baker DA: The Malaria Parasite Cyclic GMP-Dependent Protein Kinase Plays a Central Role in Blood-Stage Schizogony. Eukaryotic Cell 2010, 9:37-45.

3. Zhang J, Yang PL, Gray NS: Targeting cancer with small molecule kinase inhibitors. Nat Rev Cancer 2009, 9:28-39.

4. Deng W, Parbhu-Patel A, Meyer DJ, Baker DA: The role of two novel regulatory sites in the activation of the CGMP-dependent protein kinase from Plasmodium falciparum. Biochem J 2003, 374:559-565.

doi:10.1186/2050-6511-14-S1-P33

Cite this article as: Kim et al: Crystal structures of the carboxyl cGMP binding domain of plasmodium falciparum cGMP-dependent protein kinase reveals a novel salt bridge crucial for activation. $B M C$

Pharmacology and Toxicology 2013 14(Suppl 1):P33.

\section{Submit your next manuscript to BioMed Central} and take full advantage of:

- Convenient online submission

- Thorough peer review

- No space constraints or color figure charges

- Immediate publication on acceptance

- Inclusion in PubMed, CAS, Scopus and Google Scholar

- Research which is freely available for redistribution

Submit your manuscript at www.biomedcentral.com/submit
(Ciomed Central 